\title{
Differences in numbers of termicins expressed in two termite species affected by fungal contamination of their environments
}

\author{
P. Xu ${ }^{1}$, M. Shi ${ }^{1}$, R. Lai ${ }^{2}$ and X.-X. Chen ${ }^{1}$ \\ ${ }^{1}$ Ministry of Agriculture, Key Laboratory of Agricultural Entomology, \\ Institute of Insect Sciences, Zhejiang University, Hangzhou, China \\ ${ }^{2}$ Kunming Institute of Zoology, Chinese Academy of Sciences, \\ Kunming, China \\ Corresponding author: X.-X. Chen \\ E-mail: xxchen@zju.edu.cn
}

Genet. Mol. Res. 11 (3): 2247-2257 (2012)

Received August 16, 2011

Accepted January 27, 2012

Published May 10, 2012

DOI http://dx.doi.org/10.4238/2012.May.10.2

\begin{abstract}
Termicin is a defensin-like antimicrobial peptide of termites that has strong antifungal activity. Fifty-six different termicin mRNAs encoding 46 different peptides were amplified and identified from Odontotermes formosanus (Termitidae), a species that inhabits environments with a large variety of microbial fauna. In contrast, only 38 different termicin mRNAs encoding 21 different peptides were amplified and identified from Reticulitermes chinensis (Rhinotermitidae). All mRNAs were amplified by reverse transcript PCR, with primers designed from reported termicin mRNA sequences. All of these genes showed high intraspecific sequence identity and were found to be highly homologous with other reported termicin genes. These two termite species live in different environments; the latter encounters relatively fewer pathogens in its habitat. We conclude that differences in microenvironmental pressure can affect the number of
\end{abstract}


termicin genes expressed in termite species.

Key words: Odontotermes formosanus; Reticulitermes chinensis; Antimicrobial peptides; Termicins

\section{INTRODUCTION}

A range of defense mechanisms against microbial pathogens has been reported in social insects, including behavioral mechanisms, antimicrobial chemical production in the nest, and immune mechanisms. Group living of closely related individuals has been found to confer resistance to disease in termites, ants, and honeybees (Rosengaus et al., 1998; Hughes et al., 2002; Traniello et al., 2002; Breed et al., 2004). Antibiotic secretions are produced by metapleural glands in most ants (Beattie et al., 1986; Poulsen et al., 2002), and frontal gland secretions in one group of termites have also been shown to have antibiotic properties (Rosengaus et al., 2000). Norharmane, a $\beta$-carboline alkaloid produced by endosymbionts in termites, shows antifungal activity (Siderhurst et al., 2005a,b; Chouvenc et al., 2008). Propolis, a resinous substance collected by honeybees from various tree buds and mixed with pollen and enzymes secreted by the bees themselves, shows strong antimicrobial activity (Sforcin et al., 2000; Sawaya et al., 2002; Kartal et al., 2003; Silici and Kutluca, 2005; Souza et al., 2007). Polyandry and polygyny in social insects increase colony genetic diversity, and genetic variation within social insects can reduce parasite loads (Liersch and Schmid-Hempel, 1998; Schmid-Hempel, 1998). Positive pressure from the complex microbial environment drives Macrotermes barneyi to generate additional new peptides to defend against the invasion of pathogens (Xu et al., 2009a).

Nevertheless, innate immunity still plays a key role in the control of microbial infections in social insects. Antimicrobial peptides (AMPs) are part of the armament that social insects have developed to fight off pathogens. Termicin, a novel cysteine-rich AMP secreted by the salivary glands and hemocytes of termites and first isolated from the fungus-growing termite Pseudacanthotermes spiniger, shows a strong capability for restraining filamentous fungi but only weakly affects Gram-positive bacteria (Lamberty et al., 2001). The global fold of termicin consists of an $\alpha$-helical segment (Phe4-Gln14) and a two-stranded (Phe19-Asp25 and Gln28Phe33) antiparallel $\beta$-sheet forming a cysteine-stabilized $\alpha \beta$ motif that is also found in antibacterial and antifungal defensins in insects and plants (Da Silva et al., 2003). In total, 37 termicin peptides are encoded in one termite species, M. barneyi (Isoptera: Termitidae) (Xu et al., 2009a).

Termites feed mainly on various forms of cellulosic material and construct strikingly different nest structures in varied habitats, so they can be expected to be in close contact with various microbial environments. Some species are in contact with a complicated and diverse array of microorganisms, whereas others encounter relatively few microorganism challenges. We choose Odontotermes formosanus (Isoptera: Termitidae) and Reticulitermes chinensis (Isoptera: Rhinotermitidae), termite species living in significantly different habitats, to examine intraspecific molecular evolution strategies. $O$. formosanus is a fungus-growing termite that constructs a subterranean nest. It favors wet environments and feeds on a variety of materials such as trees, field crops, and the fungi that it cultivates. $R$. chinensis is an important urban insect pest. In the wild, it typically constructs not only subterranean nests but also nests in rotten wood on the ground. It does not cultivate fungi. It favors a relatively dry environment and feeds chiefly on ligneous architectural materials. In human dwellings, its habitats consist 
of floors, doors, window frames, and furniture, for example.

\section{MATERIAL AND METHODS}

\section{Termites}

Workers and soldiers of both termite species, O. formosanus and $R$. chinensis, were collected in Hangzhou Botanic Garden, Zhejiang Province, China (30 $16^{\prime} 6.78^{\prime \prime}$ N; $120^{\circ} 9^{\prime} 18.08^{\prime \prime}$ E) from nests wood or foraging trails. The termites were frozen in liquid nitrogen within 24 $\mathrm{h}$ of collection, stored at $-80^{\circ} \mathrm{C}$, and identified using Fauna Sinica (Huang et al., 2000) and voucher specimens deposited at the Institute of Insect Sciences, Zhejiang University, China.

\section{Isolation and characterization of termicins}

Total RNA was prepared from 20 live workers ground in liquid nitrogen. It was homogenized and extracted with an RNeasy ${ }^{\mathbb{B}}$ Mini Kit (Qiagen Gmbh, D-40724 Hilden). The complementary DNA (cDNA) libraries were constructed with a Clontech, SMART ${ }^{\mathrm{TM}}$ PCR cDNA Synthesis Kit. Double-stranded cDNA was synthesized and diluted 100-fold as the template. One specific primer (Term1: ATG AAG ACT CTC GCT ATC CTG, including the initiation codon) for 3'-rapid amplification of cDNA ends (RACE) for O. formosanus was designed from termicin mRNA sequences from the National Center for Biotechnology Information website. The coding sequence (CDS) primer (Term2: ATT CTA GAG GCC GAG GCG GCC GAC ATG) in the kit was used as the anti-sense primer. PCR conditions were $94^{\circ} \mathrm{C}$ for 2 min followed by 40 cycles $\left(20 \mathrm{~s}\right.$ at $94^{\circ} \mathrm{C}, 30 \mathrm{~s}$ at $52^{\circ} \mathrm{C}$, and $30 \mathrm{~s}$ at $72^{\circ} \mathrm{C}$ ) and $10 \mathrm{~min}$ at $72^{\circ} \mathrm{C}$. One degenerate primer (Term3: TRC TTC AKW ARA GCA TWC TGT) for 3'-RACE was designed for $R$. chinensis from the conserved region of mature peptide nucleotide sequences of other termicin mRNA genes. The CDS primer Term 2 was used as the anti-sense primer. PCR conditions were $2 \mathrm{~min}$ at $94^{\circ} \mathrm{C}$ followed by 40 cycles $\left(20 \mathrm{~s}\right.$ at $94^{\circ} \mathrm{C}, 30 \mathrm{~s}$ at $50^{\circ} \mathrm{C}$, and 30 s at $72^{\circ} \mathrm{C}$ ) and $10 \mathrm{~min}$ at $72^{\circ} \mathrm{C}$. One specific primer (Term4: GAA CCT TCC GTA TGC TAG TCT) was designed for $5^{\prime}$-RACE for $R$. chinensis according the results of the sequencing. PCR conditions were $2 \mathrm{~min}$ at $94^{\circ} \mathrm{C}$ followed by 40 cycles $\left(20 \mathrm{~s}\right.$ at $94^{\circ} \mathrm{C}, 30 \mathrm{~s}$ at $52^{\circ} \mathrm{C}$, and $30 \mathrm{~s}$ at $\left.72^{\circ} \mathrm{C}\right)$ and $10 \mathrm{~min}$ at $72^{\circ} \mathrm{C}$. Another specific primer (Term5: GTT ACAATG AGG ACT CTC TGT, including the initiation codon) was designed for 3'-RACE for $R$. chinensis according the results of the last step of sequencing. PCR conditions were $2 \mathrm{~min}$ at $94^{\circ} \mathrm{C}$ followed by 40 cycles $\left(20 \mathrm{~s}\right.$ at $94^{\circ} \mathrm{C}, 30 \mathrm{~s}$ at $50^{\circ} \mathrm{C}$, and $30 \mathrm{~s}$ at $72^{\circ} \mathrm{C}$ ) and $10 \mathrm{~min}$ at $72^{\circ} \mathrm{C}$. The PCR products were gel purified and cloned with TaKaRa pMD19$\mathrm{T}$ Vector (TaKaRa Biotechnology, Dalian, China). The clones were screened with M13 primer. To obtain the desired mRNA sequences (encoding different mature peptides and containing complete CDSs), 10-20 screened clones for each species were sent to Invitrogen Biotechnology Company (Invitrogen, Shanghai, China) repeatedly until no new sequences were found. In total, 132 screened clones for $O$. formosanus and 97 screened clones for $R$. chinensis were sequenced.

\section{Statistical analysis}

Termicin mRNA was translated into proteins using the Web Translate Tool (http://expasy. org/tools/dna.html). Protein sequences were aligned using Clustal_X version 1.81 (Higgins et al., 1996) and edited using GeneDoc (Nicholas et al., 1997). Signal peptide cleavage sites were 
predicted using the SignalP 3.0 server program (http://www.cbs.dtu.dk/services/SignalP/). Phylogenetic trees were constructed through neighbor joining analysis using Molecular Evolutionary Genetics Analysis version 4 (MEGA4) (Tamura et al., 2007). The ratio of the nonsynonymous to synonymous nucleotide substitution rate (dN/dS) was calculated using MEGA4 (Tamura et al., 2007). The positively selected sites were further detected and identified using the package Phylogenetic Analysis by Maximum Likelihood program (PAML) version 4 (Yang, 1997).

\section{RESULTS}

\section{Termicin duplication and divergence}

In total, 101 different positive clones were screened and identified, and $56 \mathrm{mRNA}$ sequences with different precursors were found in $O$. formosanus (Table 1). These 56 sequences encoded 46 different peptides (named Of1-Of46). Eighty-four positive clones were screened and identified, and 38 mRNA sequences with different precursors were found in $R$. chinensis (see Table 1). These 38 sequences encoded 21 different peptides (named Rc1-Rc21). An extra glycine is found at the C-terminal end of all of the $R$. chinensis termicin peptides except Rc3 (Figure 1) and two O. formosanus termicin peptides (Of45 and Of46; Figure 2) and all of the $R$. chinensis termicin peptides except Rc3 (Figure 1). In R. chinensis, Rc7 is the most abundant peptide, encoded by nearly two-thirds (57/84) of the positive clones; five peptides (Rc3, Rc6, Rc18, Rc19, and Rc5) are encoded by more than one positive clone, and the remaining 15 peptides are encoded by one positive clone. In $O$. formosanus, Of32 is the most abundant peptide, encoded by 15 positive clones; Of1 is encoded by 10 positive clones; Of7, Of13, and Of 23 are each encoded by 7 positive clones, and all other peptides are encoded by one or two positive clones. The results of BLAST searching suggest that all the termicin mRNA sequences show high sequence identity with reported termicin mRNA sequences.

\begin{tabular}{|c|c|c|}
\hline Species & Termicin ID & Accession No. \\
\hline Reticulitermes chinensis & Rc1-Rc38 & FJ184563-FJ184600 \\
\hline Odontotermes formosanus & Of1-Of56 & FJ184507-FJ184562 \\
\hline Nasutitermes comatus & $\mathrm{Nc1}$ & AY642891 \\
\hline Nasutitermes comatus & $\mathrm{Nc} 2$ & AY642892 \\
\hline Nasutitermes dixoni & $\mathrm{Nd}$ & AY642893 \\
\hline Nasutitermes exitiosus & $\mathrm{Ne} 1$ & AY642894 \\
\hline Nasutitermes exitiosus & $\mathrm{Ne} 2$ & AY642895 \\
\hline Nasutitermes fumigatus & $\mathrm{Nf}$ & AY642896 \\
\hline Nasutitermes graveolus & $\mathrm{Ng}$ & AY642897 \\
\hline Nasutitermes longipennis & $\mathrm{Nl}$ & AY642898 \\
\hline Nasutitermes magnus & $\mathrm{Nm}$ & AY642899 \\
\hline Nasutitermes pluvialis & $\mathrm{Np} 1$ & AY 642900 \\
\hline Nasutitermes pluvialis & $\mathrm{Np} 2$ & AY642901 \\
\hline Nasutitermes triodiae & Nt1 & AY642902 \\
\hline Nasutitermes triodiae & $\mathrm{Nt} 2$ & AY642903 \\
\hline Nasutitermes walkeri & Nw1 & AY642904 \\
\hline Nasutitermes walkeri & Nw2 & AY 642905 \\
\hline Nasutitermes walkeri & Nw3 & AY642906 \\
\hline Tumulitermes pastinator & Tp1 & AY642907 \\
\hline Tumulitermes pastinator & $\mathrm{Tp} 2$ & AY642908 \\
\hline Drepanotermes rubriceps & Dp1 & AY642909 \\
\hline Drepanotermes rubriceps & Dp2 & AY642910 \\
\hline Pseudacanthotermes spiniger & termicin & P82321 \\
\hline
\end{tabular}

Rc1-Rc38 and Of1-Of56 are found in this study, and others are downloaded from the GenBank. 


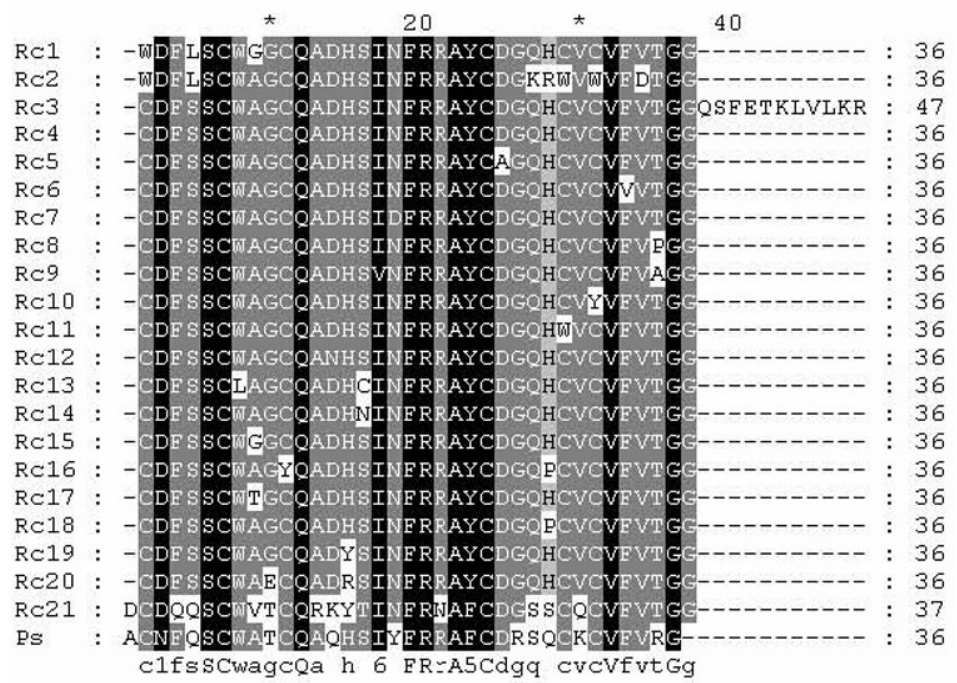

Figure 1. Protein alignments of mature termicins of Reticulitermis chinensis (Rc1-Rc21) with the first reported peptide (termed as Ps). Each termicin sequence ID is given in Table 1. Identical amino acids are in black and the partial counterparts are in gray. Small dashes indicate gaps inserted for optimal alignment. Amino acid residues are numbered on the right.

Most termicins in $R$. chinensis have 36 amino acids, except for Rc3, which has 47 amino acids, and Rc21, which has 37 (one acidic amino acid Asp is attached to the N-terminal end; see Figure 1). High percentage identity (about $90 \%$ ) occurs among termicins in $R$. chinensis, and they do not vary at one-third (12/36) of the amino acid sites $(3,6,7,12,19,20,22,24,26$, 32, 36, and 37; see Figure 1). Compared with Rc7 in R. chinensis, the other 20 peptides contain at least one non-conservative substitution (see Figure 1). Most termicins in O. formosanus contain 37 amino acids, the exceptions being Of33 and Of37, which have 49 (see Figure 2). High percentage identity also occurs among termicins in $O$. formosanus, and they do not vary at six amino acid sites $(7,8,11,13,20$, and 36; Figure 2). Compared with Of32 in O. formosanus, most peptides contain at least one non-conservative substitution; Of34 and Of39 contain one conservative substitution, and Of43 contains three conservative substitutions (see Figure 2).

\section{Termicin structure}

Eight mature peptides (Rc2, Rc3, Rc4, and Rc21 from R. chinensis, and Of1, Of3, Of33, and Of46 from $O$. formosanus), which represent all of the peptide types in these two species, were used to align with other reported termicins. The number of amino acids in the mature peptides ranged from 34 to 49 (Figure 3).

The results of the protein alignments of predicted mature termicins with the original termicin (named here Ps), which was isolated from Passalus spiniger and had antifungal activity (Lamberty et al., 2001), are shown in Figures 1 and 2. The mRNA sequences also appear to encode a signal peptide of 25 amino acids, which is absent in active termicin mature peptides and probably cleaves off after translation, whereas 24 amino acid signal peptides were encoded in other all reported termicin mRNA sequences (Bulmer and Crozier, 2004). No pro region oc- 
curs in the termicin precursor gene, which means that the active peptide was produced once it was translocated into the endoplasmic reticulum and without other processing. In addition, the termicin mRNA transcript continues for additional sequences (includes 230-270 bases) after the stop codon. Multiple stop codons in this region indicate that it is untranslated, and selective pressure is likely to be relaxed at this 3'-untranslated region (Bulmer and Crozier, 2004).

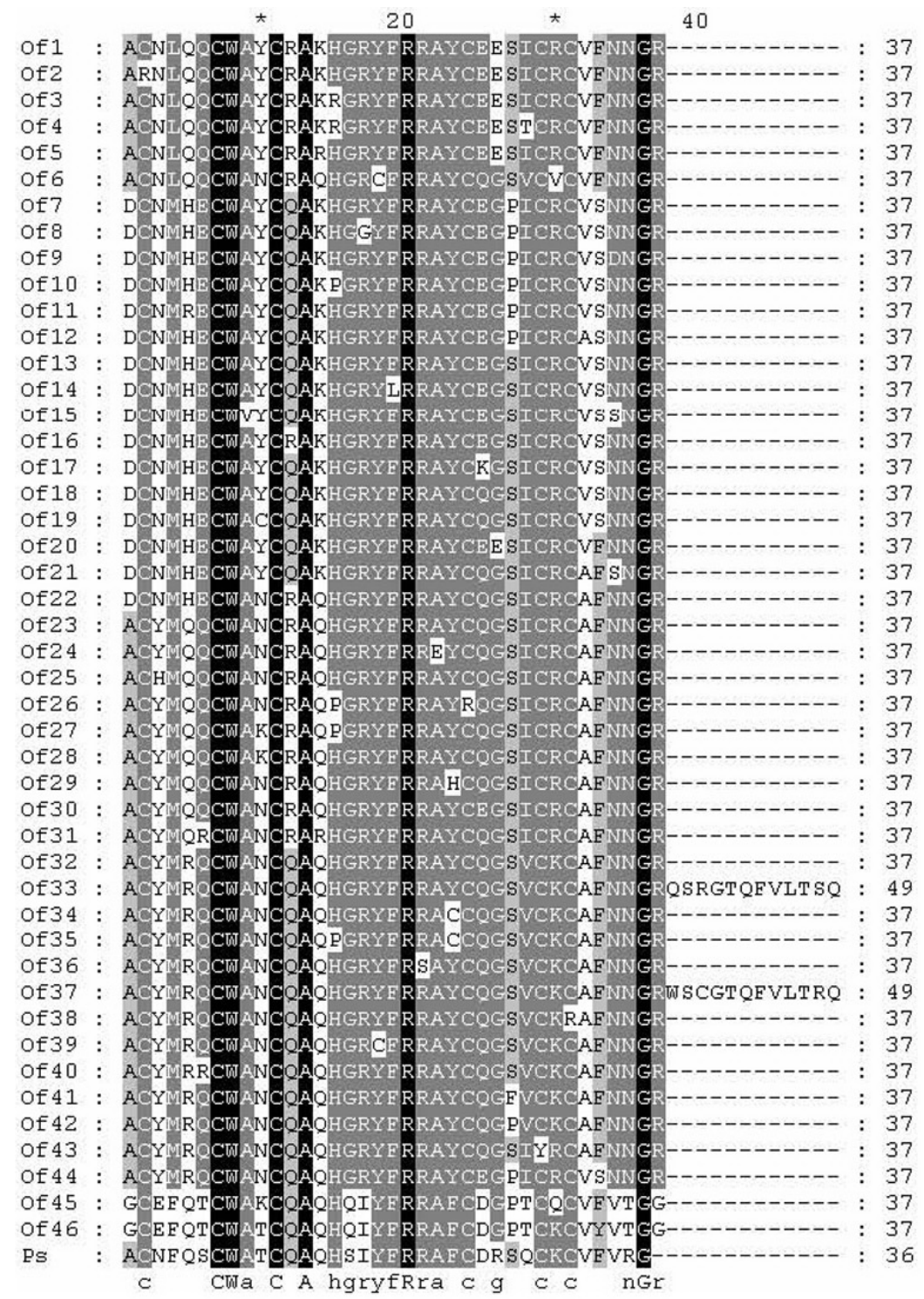

Figure 2. Protein alignments of mature termicins of Odontotermis formosanus (termed as Of1-Of46) with the first reported peptide (termed as Ps). Each termicin sequence ID is given in Table 1. Identical amino acids are in black and the partial counterparts are in gray. Small dashes indicate gaps inserted for optimal alignment. Amino acid residues are numbered on the right. 


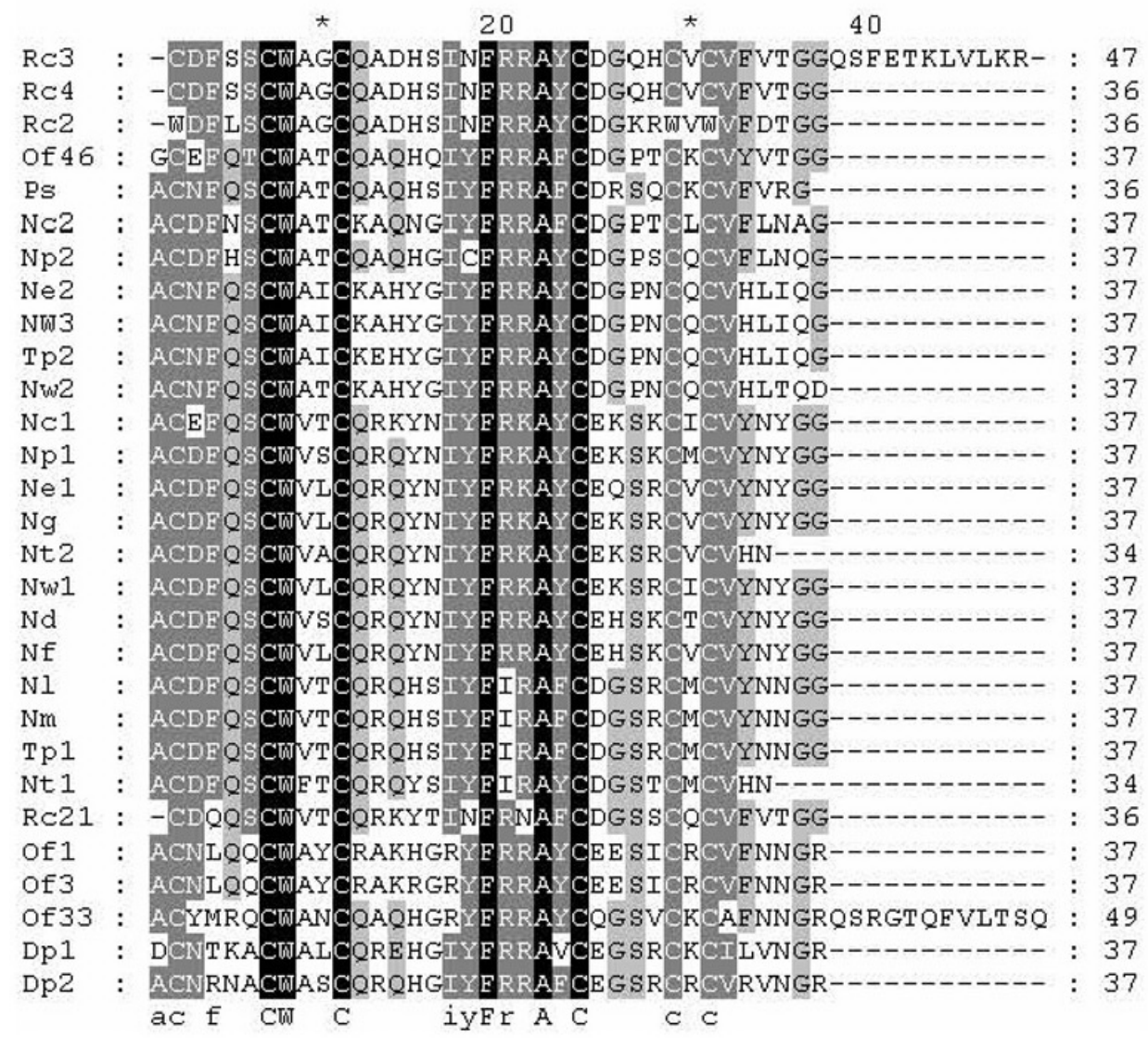

Figure 3. Protein alignments of four proteins of Reticulitermes chinensis (Rc2, Rc3, Rc4, and Rc21) and four proteins of Odontotermis formosanus (Of1, Of3, Of33, and Of46) with all other reported termicin peptides. Each termicin sequence ID is given in Table 1. Identical amino acids are in black and the partial counterparts are in gray. Small dashes indicate gaps inserted for optimal alignment. Amino acid residues are numbered on the right.

\section{Phylogenetic analysis}

We chose the mRNA sequences Of1, Of3, Of33, and Of46 from O. formosanus and $\mathrm{Rc} 2, \mathrm{Rc} 3, \mathrm{Rc} 4$, and Rc21 from R. chinensis as well as other reported mature or precursor termicin sequences to conduct a phylogenetic analysis. The chosen mRNA sequences from the two species represented all of the types of mRNA sequences.

Many of the conspecific termicins do not group together both in the tree based on the mature nucleotide sequences and in the tree based on the precursor sequences with the 3' untranslated region (Figure 4), which suggests that they are duplicated before speciation. Exceptions are the termicins in Drepanotermes rubriceps, $O$. formosanus, and $R$. chinensis, which always group together in both trees (see Figure 4), suggesting that they are probably allelic variants and that the relative genes are allelic genes. 
A

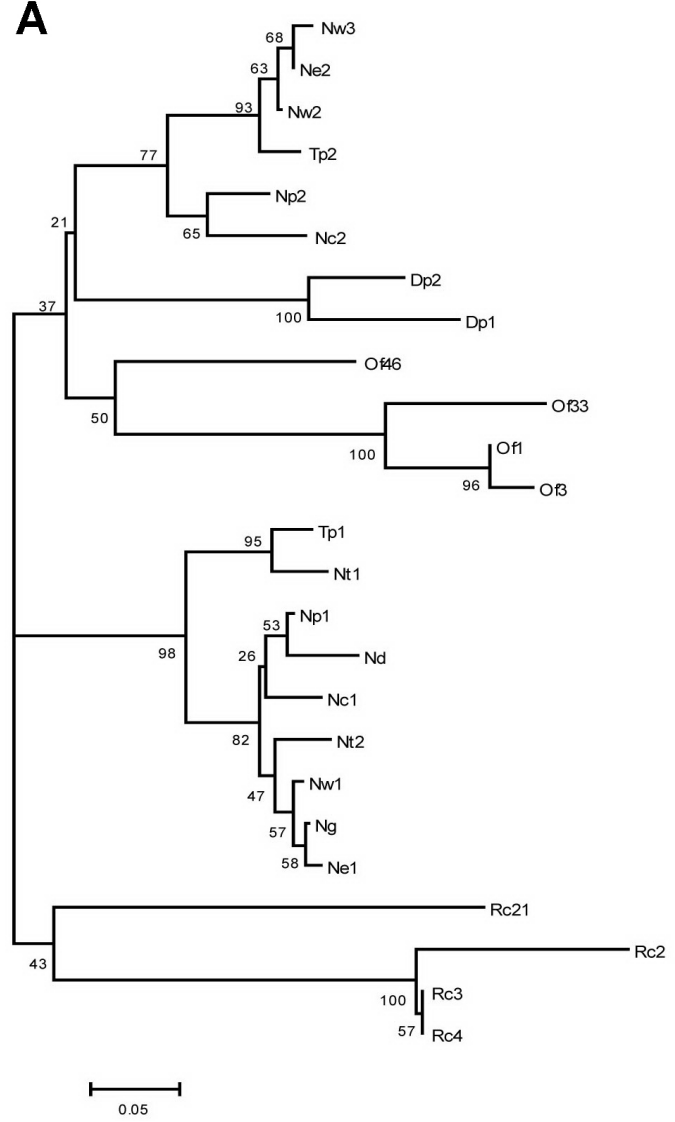

B

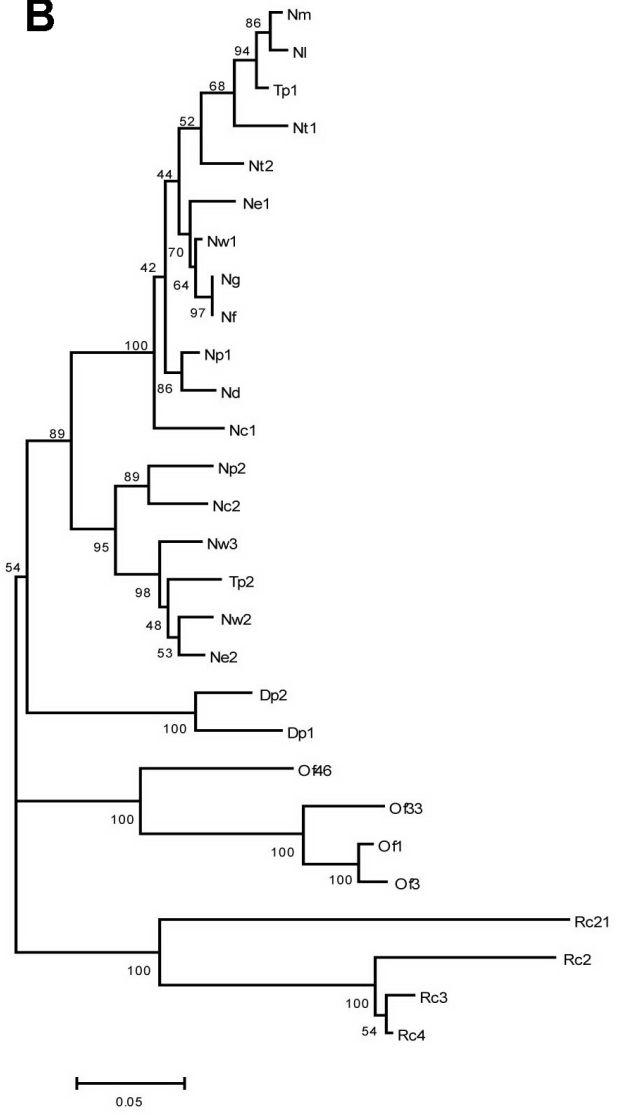

Figure 4. A. Neighbor-joining tree with bootstrap values for the mature nucleotide sequences (1000 replications). B. Neighbor-joining tree with bootstrap values for the precursor sequence with the 3'-UTR (1000 replications). Scale bars are in nucleotide substitutions per site.

\section{MEGA and PAML analysis}

We analyzed the mRNA sequences of $O$. formosanus and $R$. chinensis. All dN/dS values for the signal, mature, and precursor regions in $R$. chinensis are $<1$ (Table 2 ), which suggests that negative selection may exist and that the amino acids have been purified or maintained in $R$. chinensis termicins. The values of $\mathrm{dN} / \mathrm{dS}$ for the precursor region in $O$. formosanus are $>1$ (see Table 2), which suggests that positive selection may exist in $O$. formosanus termicins and that the amino acids have changed significantly. Values of $\mathrm{dN} /$ dS vary for different regions, which implies that selection pressure varies among sites. Positive selection in $O$. formosanus termicins (see Table 2) is manifested by rapid evolution of the mature region. Ten positively selected sites $(28 \mathrm{Y}, 30 \mathrm{Q}, 31 \mathrm{Q}, 35 \mathrm{~N}, 40 \mathrm{H}, 50$ Q, 52 S, 53 I, $55 \mathrm{R}$, and $57 \mathrm{~A}$ ) with $\mathrm{P}$ values of $>99 \%$ were detected and identified for $O$. formosanus termicins, and all the sites are in the mature region. 


\begin{tabular}{|c|c|c|c|c|c|c|}
\hline \multirow[t]{2}{*}{ Species } & \multicolumn{3}{|c|}{ Nei-Gojobori Method (Jukes-Cantor) } & \multicolumn{3}{|c|}{ Modified Nei-Gojobori (Jukes-Cantor) } \\
\hline & Signal region & Mature region & Precursor region & Signal region & Mature region & Precursor region \\
\hline R. chinensis & 0.686 & 0.582 & 0.647 & 0.864 & 0.826 & 0.878 \\
\hline O. formosanus & 0.463 & 1.628 & 1.375 & 0.553 & 2.21 & 1.8 \\
\hline
\end{tabular}

$\mathrm{dN} / \mathrm{dS}=$ nonsynonymous to synonymous nucleotide substitution rate.

\section{DISCUSSION}

We report 94 termicin mRNA sequences from the two species and characterize 67 new termite termicins ( 21 for $R$. chinensis and 46 for $O$. formosanus) that show high sequence identity to other reported termicins. This amplification and identification of all termicin mRNA genes from two termite species is a first. These data increase the known nucleotide sequence diversity of termicins more than 4-fold. Our comparison of two termite species shows that $O$. formosanus, which lives in an environment with strong microorganism challenges, has a significantly larger number of AMPs than that of $R$. chinensis, which lives in a relatively "clean" environment. The results of our phylogenetic analysis (see Figure 4) show that unlike most previously reported termicins, which differ at a substantial number of sites and are unlikely to be allelic variants (Bulmer and Crozier, 2004), the conspecific termicins in the two species we studied (R. chinensis and $O$. formosanus) are homogeneous, suggesting that they are allelic variants. The most abundant peptide in $O$. formosanus termicins, Of32, is encoded by $14.3 \%(15 / 105)$ of the positive clones, indicating that all of the peptides may play a similar role in the immune humoral system. The most abundant peptide in R. chinensis termicins, Rc7, is encoded by $67.9 \%(57 / 84)$ of the positive clones, indicating that other peptides are likely to be complementary to Rc7.

It seems that the stronger the microenvironmental pressures a species encounters, the more AMPs or peptides with stronger antimicrobial ability it will generate. For example, 30 AMP families including 107 different peptides were purified and characterized from one amphibian frog (Odorrana grahami Boulenger; Li et al., 2007). This frog lives in small streams at high elevation and is surrounded by complex microbial fauna. In contrast, only 16 AMPs in 4 humoral AMP families are reported from the famous eusocial insects the honeybee Apis mellifera (Casteels et al., 1989, 1990, 1993; Casteels-Josson et al., 1993, 1994; Klaudiny et al., 2005; Zhou et al., 2008) and the Asiatic honey bee Apis cerana (Xu et al., 2009b), which encounter far less microenvironmental pressure than that encountered by $O$. grahami or most termite species.

The living environments of termites host a diversity of microorganisms, such as fungi, bacteria, eukaryotic parasites, and viruses; fungi are the major pathogen of most termite species. Plentiful AMPs likely play an important role in assuring that termites survive the presence of pathogenic microorganisms. Positive pressure from the complicated microbial environment drives $M$. barneyi to generate additional new peptides to defend against the invasion of the pathogens (Xu et al., 2009a). Although almost all termites live in a complex microbial environment and some termite species are closely related, they are still expected to face different microenvironmental pressures. The more complicated microbial environment and higher level of microorganism challenge of $O$. formosanus compared with that of $R$. chinensis is likely be the key reason that the former generates more termicin genes. At the same time, the $\mathrm{dN} / \mathrm{dS}$ values for the termicin precursor genes in these two termite species may hint that the 
termicin genes in $O$. formosanus, which faces stronger microenvironmental pressure, may adopt positive evolution strategies, whereas they adopt negative evolution strategies in $R$. chinensis, which comes into contact with weaker microenvironmental pressure.

\section{ACKNOWLEDGMENTS}

We thank Dr. M. Sharkey (University of Kentucky, USA) and Dr. N.E. Pierce (Harvard University, USA) for their comments and for improving the manuscript. Research supported by the National Natural Science Foundation of China Fund for Innovative Research Groups (\#31021003), the Zhejiang Key Program of Agriculture (\#2009C12048), the National Natural Science Foundation of China (\#30871675), and the Research Fund for the Doctoral Program of Higher Education (\#200803350092).

\section{REFERENCES}

Beattie AJ, Turnbull CL, Hough T and Knox RB (1986). Antibiotic production: a possible function for the metapleural glands of ants (Hymenoptera: Formicidae). Ann. Entomol. Soc. Am. 79: 448-450.

Breed MD, Guzman-Novoa E and Hunt GJ (2004). Defensive behavior of honey bees: organization, genetics, and comparisons with other bees. Anпu. Rev. Entomol. 49: 271-298.

Bulmer MS and Crozier RH (2004). Duplication and diversifying selection among termite antifungal peptides. Mol. Biol. Evol. 21: 2256-2264.

Casteels-Josson K, Capaci T, Casteels P and Tempst P (1993). Apidaecin multipeptide precursor structure: a putative mechanism for amplification of the insect antibacterial response. EMBO J. 12: 1569-1578.

Casteels-Josson K, Zhang W, Capaci T, Casteels P, et al. (1994). Acute transcriptional response of the honeybee peptideantibiotics gene repertoire and required post-translational conversion of the precursor structures. J. Biol. Chem. 269: 28569-28575.

Casteels P, Ampe C, Jacobs F, Vaeck M, et al. (1989). Apidaecins: antibacterial peptides from honeybees. EMBO J. 8: 2387-2391.

Casteels P, Ampe C, Riviere L, Van DJ, et al. (1990). Isolation and characterization of abaecin, a major antibacterial response peptide in the honeybee (Apis mellifera). Eur. J. Biochem. 187: 381-386.

Casteels P, Ampe C, Jacobs F and Tempst P (1993). Functional and chemical characterization of Hymenoptaecin, an antibacterial polypeptide that is infection-inducible in the honeybee (Apis mellifera). J. Biol. Chem. 268: 7044-7054.

Chouvenc T, Su NY and Elliott MI (2008). Antifungal activity of the termite alkaloid norharmane against the mycelial growth of Metarhizium anisopliae and Aspergillus nomius. J. Invertebr. Pathol. 99: 345-347.

Da Silva P, Jouvensal L, Lamberty M, Bulet P, et al. (2003). The solution structure of termicin from hemocytes of the termite Pseudacanthotermes spiniger. Protein Sci. 12: 438-446.

Higgins DG, Thompson JD and Gibson TJ (1996). Using Clustal for Multiple Sequence Alignments. In: Computer Methods for Macromolecular Sequence Analysis (Doolittle RF, ed.). Academic Press Inc., San Diego, 383-402.

Huang F, Zhu S, Ping Z, He X et al. (2000). Fauna Sinica. Insecta, Isoptera. Vol. 17. Science Press, Beijing.

Hughes WO, Eilenberg J and Boomsma JJ (2002). Trade-offs in group living: transmission and disease resistance in leafcutting ants. Proc. Biol. Sci. 269: 1811-1819.

Kartal M, Yildiz S, Kaya S, Kurucu S, et al. (2003). Antimicrobial activity of propolis samples from two different regions of Anatolia. J. Ethnopharmacol. 86: 69-73.

Klaudiny J, Albert S, Bachanova K, Kopernicky J, et al. (2005). Two structurally different defensin genes, one of them encoding a novel defensin isoform, are expressed in honeybee Apis mellifera. Insect Biochem. Mol. Biol. 35: 11-22.

Lamberty M, Zachary D, Lanot R, Bordereau C, et al. (2001). Insect immunity. Constitutive expression of a cysteine-rich antifungal and a linear antibacterial peptide in a termite insect. J. Biol. Chem. 276: 4085-4092.

Li J, Xu X, Xu C, Zhou W, et al. (2007). Anti-infection peptidomics of amphibian skin. Mol. Cell Proteomics 6: 882-894.

Liersch S and Schmid-Hempel P (1998). Genetic variation within social insect colonies reduces parasite load. Proc. R. Soc. Lond. B 265: 221-225.

Nicholas KB, Nicholas HB Jr and Deerfield DW (1997). GeneDoc: Analysis and visualization of genetic variation. EMBNEW News 4: 14. 
Poulsen M, Bot ANM, Nielsen MG and Boomsma JJ (2002). Experimental evidence for the costs and hygienic significance of the antibiotic metapleural gland secretion in leaf-cutting ants. Behav. Ecol. Sociobiol. 52: 151-157.

Rosengaus RB, Maxmen AB, Coates LE and Traniello JFA (1998). Disease resistance: a benefit of sociality in the dampwood termite Zootermopsis angusticollis (Isoptera: Termopsidae). Behav. Ecol. Sociobiol. 44: 125-134.

Rosengaus RB, Lefebvre ML and Traniello JFA (2000). Inhibition of fungal spore germination by Nasutitermes: evidence for a possible antiseptic role of soldier defensive secretions. J. Chem. Ecol. 26: 21-39.

Sawaya AC, Palma AM, Caetano FM, Marcucci MC, et al. (2002). Comparative study of in vitro methods used to analyse the activity of propolis extracts with different compositions against species of Candida. Lett. Appl. Microbiol. 35: 203-207.

Schmid-Hempel P (1998). Parasites in Social Insects. Princeton University Press, Princeton.

Sforcin JM, Fernandes Jr A, Lopes CA, Bankova V, et al. (2000). Seasonal effect on Brazilian propolis antibacterial activity. J. Ethnopharmacol. 73: 243-249.

Siderhurst MS, James DM, Blunt TD and Bjostad LB (2005a). Antimicrobial activity of norharmane against the entomopathogenic fungus Metarhizium anisopliae (Metsch) and the caste and phylogenetic distribution of this defense in termites (Insecta: Isoptera). Sociobiology 46: 563-577.

Siderhurst MS, James DM, Blunt TD and Bjostad LB (2005b). Endosymbiont biosynthesis of norharmane in Reticulitermes termites (Isoptera: Rhinotermitidae). Sociobiology 45: 687-705.

Silici S and Kutluca S (2005). Chemical composition and antibacterial activity of propolis collected by three different races of honeybees in the same region. J. Ethnopharmacol. 99: 69-73.

Souza RM, de Souza MC, Patitucci ML and Silva JF (2007). Evaluation of antioxidant and antimicrobial activities and characterization of bioactive components of two Brazilian propolis samples using a pKa-guided fractionation. $Z$. Naturforsch. C 62: 801-807.

Tamura K, Dudley J, Nei M and Kumar S (2007). MEGA4: Molecular Evolutionary Genetics Analysis (MEGA) software version 4.0. Mol. Biol. Evol. 24: 1596-1599.

Traniello JF, Rosengaus RB and Savoie K (2002). The development of immunity in a social insect: evidence for the group facilitation of disease resistance. Proc. Natl. Acad. Sci. U. S. A. 99: 6838-6842.

Xu P, Shi M and Chen XX (2009a). Positive selection on termicins in one termite species, Macrotermes barneyi (Isoptera: Termitidae). Sociobiology 53: 739-753.

Xu P, Shi M and Chen XX (2009b). Antimicrobial peptide evolution in the Asiatic honey bee Apis cerana. PLoS One 4: e4239.

Yang Z (1997). PAML: a program package for phylogenetic analysis by maximum likelihood. Comput. Appl. Biosci. 13: $555-556$.

Zhou XX, Wang YB, Pan YJ and Li WF (2008). Nisin-controlled extracellular production of apidaecin in Lactococcus lactis. Appl. Microbiol. Biotechnol. 78: 947-953. 